\title{
COCONUT YIELD IMPROVEMENT IN FARMERS' FIELDS THROUGH RESEARCH-BASED FERTILIZATION MANAGEMENT IN THE PHILIPPINES
}

\author{
Severino S. Magat Ph.D. ${ }^{1 /}$
}

\begin{abstract}
For the past 20 years, the development of leaf analysis or foliar diagnosis ofcoconut, supported and confirmed by a network offertilizer experiments (onstation and on-farm trials) demonstrated the significance of improving coconut yields in terms Of nuts and copra through balance nutrition or fertilization ofpalms.

In the Philippines, emphasis on the correction of the widespread deficiencies in $\mathrm{N}, \mathrm{Cl}, \mathrm{S}$ and $\mathrm{K}$ had been achieved even in small-scale farms with $142 \%$ average increase in nut yield and $179 \%$ increase in copra terms after 3-4 years of application at moderate rates offertilizers.

Research findings are discussed in relation to the coconut rehabilitation of mature stands and the utilization of coconut hybrids in the - sustainable coconut development.
\end{abstract}

\section{INTRODUCTION}

Coconut (Cocos nucifera) a perennial vegetable oil crop rich in $\mathrm{C}_{12}$ or Launc acid is one of the most important food and cash crops grown in the tropical belt of the world. It is widely adapted to the enviroriments and chmatic conditions of many producing countries, notably occupying over 20 percent of the available arable land in most of these countries. It is a major contributor to the economies of many Asian and Pacific Coconut Community member countries or APCC as well as other producing countries and plays a global role in the edible oils market. However, its long term stability and security is unlikely if it is not able to demonstrate its economic viability to produce.

The prospects of the industry remains bright if one considers the products derived, and that can still be derived, from coconut, the acceptability of these products in the market, and. the intrinsic characteristics of coconut, not the least of which are biodegradability and the enviromnent-friendliness of its products. Palm oil., palm kernel oil, rapeseed arid soybean and other vegetable oils compete with coconut only in the oil and meal products, not as food or as health drink in the industrial uses of the shell and the husk of coconut,

To be globally competitive, the industry has to modernize in its agricultural production, product processing, and improve the marketing and utilization of coconut and its products. Hence, micreased. productivity, profitability and cost-efficiency in coconut farming should be necessary now and mi the coming millennium.

Moreover, as farmlands in the country will be significantly reduced in hectarage, because of the competition for industrial, commercial and residential uses, research should. be focused in generating technologies that further increased coconut yield and at the same time maximized utilization and profitability of coconut lands. These shoidd lead to higher- economic viability and sustainability of farms that provide very attractive incomes to farmers the main motivating factor to produce more coconuts for the industry.

\footnotetext{
${ }^{1}$ Scientist IV and Department Manager, Agricultural Research Management Department, Philippine Coconut Authority.
} 
In this paper we aim to present some, of the salient $R \& D$ results of the efforts of the Philippine Coconut Authority (PCA) on crop nutrition and fertilization studies in support of enhanced coconut productivity and sustainable production.

\section{COCONUT YEELD GAPS UNDER PHHIEPPINE CONDITIONS}

Yields of coconut aclueved $\mathrm{m}$ the country sigrnficantly vary depending on agro-climatic factors and level of fann management (Table 1). Under research stations (PCA) the average yield is 107 nuts/tree (3.60 t copra/ha) annually. Figure I shows a wide gap of 48 nuts/tree (1.77 t copra) between the umnanaged farms (e.g. SCFDP) and managed farms (farmers) but the gap between the research stations and managed farms is about 24 nuts/tree or $0.90 \mathrm{t}$ copra. This indicates that application of practical and viable technologies as judicious fertilization could narrow the yield gap and increase agricultural production efficiency mi the country.

Table 1. Coconut Yield Gap: Research Center, Improved Farms and Unmanaged Farms ( aguna Tall Variety)

\begin{tabular}{|c|c|c|c|c|c|}
\hline \multirow{3}{*}{ Reference } & \multirow{3}{*}{$\begin{array}{c}\text { Planting } \\
\text { Density } \\
\text { Palms/ha }\end{array}$} & \multicolumn{4}{|c|}{ Average Yield/Year } \\
\hline & & \multicolumn{2}{|c|}{ Nut/Tree } & \multicolumn{2}{|c|}{ Copra/Ha (t) } \\
\hline & & W/O F1 & With F2 & W/O F1 & With F2 \\
\hline \multicolumn{6}{|l|}{ Davao Research Center (DRC) } \\
\hline $\begin{array}{l}\text {-KCl Study } \\
\text { (Magat et al, 1975) }\end{array}$ & 156 & 71.00 & 96.50 & 1.77 & 2.64 \\
\hline $\begin{array}{l}\text {-NaCl Study } \\
\text { (Magat et al, 1992) }\end{array}$ & 156 & 93.50 & 127.70 & 1.90 & 3.74 \\
\hline $\begin{array}{l}\text {-NPK Study } \\
\text { (Prudente \& Mendoza 1979) }\end{array}$ & 156 & 25.60 & 61.40 & 0.71 & 2.75 \\
\hline $\begin{array}{l}\text {-Cl Nutrition Study } \\
\text { (Magat and Margate, 1990) }\end{array}$ & 143 & 63.10 & 79.20 & 1.93 & 3.24 \\
\hline DRC Average & & 63.30 & 91.20 & 1.58 & 3.09 \\
\hline \multicolumn{6}{|l|}{ Zamboanga Res. Center (ZRC) } \\
\hline $\begin{array}{l}\text {-Genetic Block-Laguna } \\
\text { ( Breeding \& Genetics, 1995) }\end{array}$ & 143 & - & 123.00 & 0 & 4.10 \\
\hline $\begin{array}{l}\text {-SCFDP Farms3 } \\
\text { (Magat, 1995) }\end{array}$ & 138 & 35.00 & 83.00 & 1.02 & 2.79 \\
\hline $\begin{array}{l}\text {-PCA Leaf Nutrition Survey } \\
\text { (Magat et al, 1981) }\end{array}$ & 110 & 36.00 & $(81.00)^{*}$ & 0.88 & $(1.98)^{*}$ \\
\hline Research Station Average & & - & 107.10 & - & 3.60 \\
\hline \multicolumn{6}{|c|}{$\begin{array}{l}\text { 1-Without Fertilzer Application } \\
\text { 2-With Fertilizer Application } \\
\text { 3-Small Coconut Farms Development Project (World Bank-assisted) } \\
\text { *-High yielding farms }\end{array}$} \\
\hline
\end{tabular}




\section{COCONUT YIELD GAP \\ Research Center, Improved Farms \& Unmanaged Farms \\ (Laguna Tall Variety)}
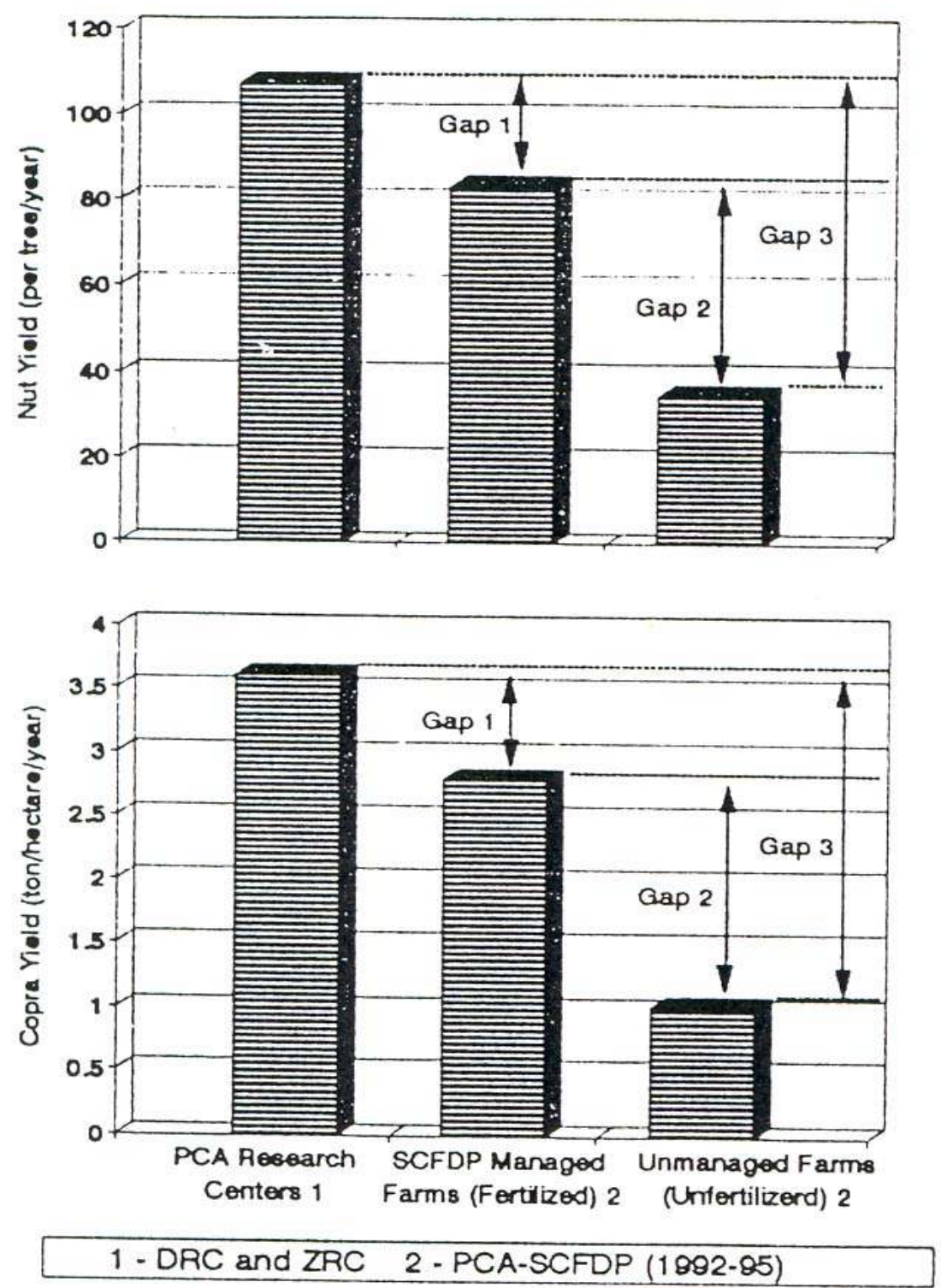

Figure1. Influence of technology transfer (fertilizer application) under the World Bank-assisted Small Coconut Farms Development Priject on the average yield gaps (nut and copra) between PCA Research Stations and Farmers practic (unmanaged farms).

\section{MINERAL NUTRITION AND FERTILIZATION}

Over the past 30 years, efforts in the Philippines are focused to have reliable tools in detennining the nutritional status and needs of palms and response to fertilization under different growing zones. In chronological order, in retrospection, the R\&D highlights and milestones achieved are presented in Box 1. 


\section{Box 1. R\&D Milestones Achieved In Mineral Nutrition Management and Fertilizer Advisory}

(1972-1995).

-1972 - Findings on growth and the economic responses of coconut to KCI application in NPK Fertilization studies started in 1964 and 1968 at Davao; first circurnstantial evidence of the beneficial effect of Chlorine (CI) on coconut by several workers notably Mendoza and Prudente).

-1975 - Low yields of inland coconuts improved by correcting the $\mathrm{Cl}$ deficiency by $\mathrm{KCl}$ application confirmed the positive relationship of leaf $\mathrm{Cl}$ and yield with a quadratic response and linear response in terms of nut and copra. (weight/nut, copra/tree), respectively. (Magat, Cadigal and Habana).

-1977 - Sodium Chloride or common salt as an. effective and cheaper fertilizer and for the control of leaf spot disease of coconut seedlings (Magat, Margate and Prudente).

$-1978-\mathrm{KCl}$ fertilizer significantly reduced incidence of leaf spot fungus diseases in young pahm and bearing pahns, indicating the fungus disease is strongly assoclated with deficiency in $\mathrm{Cl}$ (Abad, Prudente and Magat).

-1978 - In a long-term KCl application (1972-1977). $2 \mathrm{~kg} \mathrm{KCl} /$ tree proved to be most economic rate while highest copra weight/nut and yield/tree obtained at $8 \mathrm{~kg} \mathrm{KCI} /$ tree/year (Margate, Magat, Alforja and Habana).

-1978 - The usefulness of leaf analysis in the conduct of field fertilizer trials in the Philippines was reported internationally for the first time (Magat).

-1981 - Inland coconuts suffering from N, CI and S deficiencies economically corrected with the application of $1.8 \mathrm{~kg}$. $\left(\mathrm{NH}_{4}\right)_{2}+\mathrm{SO} 4+1.8 \mathrm{~kg} \mathrm{NaCl}$ or $1.8 \mathrm{~kg}\left(\mathrm{NH}_{4}\right)_{2}+\mathrm{SO} 4+2 \mathrm{~kg} \mathrm{KCl}$ /tree/year (Magat, Maravilla and Padrones).

-1981 - The nationwide leaf survey (1978-1980) revealed the widespread deficiency in $\mathrm{N}, \mathrm{Cl}$ and $\mathrm{S}$ of the existing stands of local tall coconuts; and could be grouped into 10 distinct deficiencies classes, including the $\mathrm{K} . \mathrm{P}$ and $\mathrm{Mg}$ deficiencies in some areas (Magat, Habana, Escoton, Labarcon and Frollan).

-1988 - As KC1 fertilizer, it was confirmed that common salt (NaCI) increases nut production, copra weight/nut, and copra yield/tree, with leaf $\mathrm{N}$ as the main determinant of nut yield, while leaf $\mathrm{Cl}$ for copra (weight/nut, yielcl/tree), using $\mathrm{NaCl}$ rates: 0.88, 1.76, 3.52 and 7.04/tree/year (Magat, Margate and Habana).

-1988 - An estimate of the leaf Sulfur (S) critical and optimum levels for bearing coconuts revealed to be $0.12 \%$ and $0.19 \%$ of leaf No. 14 (Magat, Alforja and Margate).

-1988 - For-the first time, an estimate of the critical and optimurn levels of coconut leaf $\mathrm{Cl}$ found to vary with yield indices, as: leaf 14 critical level (both nuts and copra) $-0.30 \% \mathrm{Cl}$; optimurri level: nut/tree $0.51 \% \mathrm{Cl}$; copra./nut- $0.55 \% \mathrm{Cl}$ and copra/tree $-0.63 \% \mathrm{Cl}$ (Magat, Alforja and Oguis).

-1989- The optimum leaf-K of bearing palms identified: $0.81 \% \mathrm{~K}$ (in terms of nut yield); $1.0 \%$ $\mathrm{K}$ (copra/nut); 0.90\% K (copra yield/tree) of leaf rank 14 (Magat and Padrones). 
Box 1. Continuation ...

-1990 - The chlorine needs of coconuts (from nursery to bearing stage) presented by PCA-DRC, based on the 15 years research work on coconut from nursery to fullbearing (1974-1999) (Magat and Margate).

-1990 - The use of salt (sodium chloride) generally recognized for public dissernination through PCARRD's Technology! series (Magat).

-1992 - PCA-DRC reported a computerized fertilizer recommendation for coconut based on fohar analysis using a Lotus 123 Software Package System, aimed at facilitating formulation of specific fertilizer recommendation. (Margate, Secretaria, Magat and Alforja).

-1992 - The positive residual effects of common salt (N\&CI) fertilizer on yield and leaf nutrient of coconuts revealed, indicating adequate leaf-Cl and stable yields wiffiin 3 years after the 3-5 regular annual fertilizer (Magat, Habana and Alforja).

-1993 - Three chloride sources $\left(\mathrm{KCI}, \mathrm{NaCl}\right.$ and $\mathrm{NH}_{4} \mathrm{CI}$ ) showed similar positive residual effects when applied at $0.80 \mathrm{~kg} \mathrm{Cl} /$ tree/year. High yields maintained by palms attributed to maintenance of leaf $\mathrm{Cl}$ at $0.50-0.60 \%$ even after diree successive years of fertilizer applications (Magat, Padrones and Alforja).

-1995 - Findings on the agronomic effectiveness of single fertilizers as $\left(\mathrm{NH}_{4}\right)_{2}+\mathrm{SO}_{4} \mathrm{KCl}$. NaCl used in the rehabilitation of SCFDP farms, resulting in average increase of $142 \%$ (nuts) and 179\% (copra), 241\% (net income) by 3-4 annual 1 fertilizer -applications (Magat).

-1995- In a long-term. nationwide on-farm. fertilizer 1 trials (OFFTs), as in local talls, hybrids produced significantly higher yields only when adequate $\mathrm{Cl}$ fertilizer supplied to palms or organic fertilizers must be combined with inorganic $\mathrm{Cl}$ fertilizers as $\mathrm{NaCl}$ or $\mathrm{KCl}$ to be cost-effective (Margate, Secretaria, Padrones, Maravilla, Magat, Mantiquilla, Silva, Corsane, Borromeo and Rivera.).

\section{VARIETAL RESPONSE TO FERTELIZATION}

On bean crop (Phoseolus vulgaris L.), Malavolta and Amaral (1978) used Nutritional Efficiency (E) defined as yield/element absorbed by the crop. They found a strong positive correlation between $\mathrm{E}$ value and yield, and claimed that nutritional efficiency a useful parameter in the selection and/or screening of varieties.

Also, on com inbreds (OPVS) and hybnids, the efficiency of phosphorus utilization in relation to yield under field conditions of these cultivars was reported to be a useful index in screening better planting materials (Fox, 1987). While on tornato, O' Sullivan et al (1974), claimed that also dry matter production (vegetative and fruits) of the crop indicated varied nutritional efficiency to nitrogen applied.

Agricultural and horticultural crops have different capabilities to utilize the available nutrients (from the soll and the applied fertilizers) mi producmig the desired harvest. This is measured by yield response midex as response ratio (yield per $\mathrm{kg}$ nutrient applied) or yield per $\mathrm{kg}$ fertilizer applied. Recently, crop fertilizer use efficiency analysis (CFE) on coconut production was introduced by the PCA (Magat, 1996). 
In the Coconut MULTILOC Project (PCA-PCARRD-Private sectors initiative), as the common fertilizer applied to all enthies (Table 2) supplied two or more nutrients (e.g. N, P, K, S, Cl, $\mathrm{Mg}$. B) at a moderate rate of fertilization (based on the annual leaf analysis of coconut samples), the average total amount of fertilizers for the last three years of the expeniment was used in this arialysis (Table 3).

Table 2. Entries of Promising Tall Cultivars and Hybrids Tested in the MULTILOC Sites (9), 1985-1995, Philippines

\begin{tabular}{|c|c|c|c|}
\hline \multirow[t]{2}{*}{ Entry $^{1}$} & \multicolumn{3}{|c|}{ Cultivar and Parental Materials } \\
\hline & Tall & Female & Male \\
\hline BAY & Baybay & - & \\
\hline LAG & I & & - \\
\hline The & Laguira & - & - \\
\hline TAG & Tagnanan & - & - \\
\hline MUL & Mulanay & - & - \\
\hline LON & Loong & - & - \\
\hline LAP & Lapasan & - & \\
\hline HJT & Hijo & - & West African Tall \\
\hline MYD x WAT & - & Malayan Yellow Dwarf & Rennel Tall \\
\hline MYD x RIT & - & Malayan Yellow Dwarf & Rennel Tall \\
\hline MRD x RIT & - & Malayan Red Dwarf & Tagnanan Tall \\
\hline MRD x TAG & - & Malayan Red Dwarf & Bavhay Tall \\
\hline MRD x BAY & - & Malayan Red Dwarf & Hijo Tall \\
\hline MRD x HJT & - & Malayan Red Dwarf & Bago-Oshiro Tall \\
\hline TAC $\times$ BAO & - & Tacunan Green Dwarf & Lunisan Tall \\
\hline PGD x LUP & - & Pascual Green Dwarf & Ravhay Tall \\
\hline CAM x BAY & - & Camotes Green Dwarf & Rennel Tall \\
\hline WAT x RIT & - & West African Tall & Bavbay Tall \\
\hline TAC $\times$ BAY & - & Tacunan Green Dwarf & \\
\hline
\end{tabular}

${ }^{1)}$ Hybrids were produces by several participating agencies (PCA, All, TRRC, ViSCA, UPLB) following either the controlled pollination hybridization techniques. Raised in field nursery prior to field-planting.

Table 3. MULTILOC Sites Average Total Rate of Fertilizers Applied

\begin{tabular}{|l|c|c|c|c|c|}
\hline \multirow{2}{*}{ MULTILOC Site } & \multicolumn{5}{|c|}{ Kg Fertilizer (per tree/year) $)^{1}$} \\
\cline { 2 - 6 } & 1993 & 1994 & 1995 & Total & Avg \\
\hline $\begin{array}{c}\text { 1. Mulanay, Quezon } \\
\text { (Farmer-Sikat Nanadiego) }\end{array}$ & 2.70 & 3.50 & 2.50 & 8.70 & 2.90 \\
\hline $\begin{array}{c}\text { 2. Mambuaya, Cagayan } \\
\text { De Oro City }\end{array}$ & 4.00 & 3.00 & 3.50 & 10.50 & 3.50 \\
\hline $\begin{array}{c}\text { 3. Tagum, Davao Norte } \\
\text { (TRRC-Hijo Plantation) }\end{array}$ & 4.50 & 4.40 & 4.25 & 13.15 & 4.38 \\
\hline
\end{tabular}

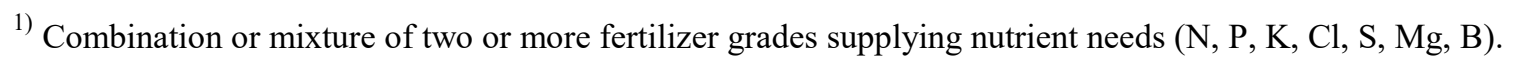




\section{Mulanay, Quezon (Sikat Nanadiego farm)}

The site is situated in an intermediate growing zone with type B - humid climate. At nine years from FP, the best entry in terms of CFEn is MRD x BAY (CFEn = 26.90) and MRD x TAG in tenns of CFEc $(=7.42)$ (Table 4$)$, suggesting that with similar nut yields MRD x TAG hybrid had higher copra weight/nut, thus the higher- CFEc.

Table 4. Index of Crop Fertilizer Efficiency (CFE) of Entries in MULTILOC -Mulanay, Quezon (Farmer-Cooperator)

\begin{tabular}{|l|c|c|c|c|c|c|c|}
\hline \multirow{2}{*}{ Entry } & \multirow{2}{*}{ Kg FA $^{1}$} & \multirow{2}{*}{$\mathrm{N}^{2} \mathrm{P}^{2}$} & C/P & \multicolumn{2}{|c|}{ CFE } & \multicolumn{2}{c|}{ CFE Rank } \\
\cline { 5 - 8 } & & $(1995)$ & $(1995)$ & $\mathrm{CFEn}^{4}$ & CFEc $^{5}$ & CFEn & CFEc \\
\hline & & & & & & & \\
MYD x WAT & 2.70 & 50.20 & 11.08 & 18.60 & 4.10 & 5 & 7 \\
MYD x RIT & 2.70 & 41.00 & 11.16 & 15.20 & 4.13 & 7 & 6 \\
MRD x RIT & 2.70 & 44.10 & 10.88 & 16.30 & 4.03 & 6 & 8 \\
MRD x TAG & 2.70 & 71.00 & 20.04 & 26.30 & 7.42 & 2 & 1 \\
MRD x BAY & 2.70 & 72.60 & 19.90 & 26.90 & 7.37 & 1 & 2 \\
MRD x HJT & 2.70 & 59.70 & 16.31 & 22.00 & 6.04 & 3 & 3 \\
PGD x LUP & 2.70 & 54.70 & 13.90 & 20.20 & 5.15 & 4 & 4 \\
CAM x BAY & 2.70 & 26.90 & 7.55 & 9.90 & 2.79 & 10 & 10 \\
BAY & 2.70 & 39.20 & 11.71 & 14.50 & 4.34 & 8 & 5 \\
TAG & 2.70 & 9.90 & 2.43 & 3.70 & 0.66 & 11 & 11 \\
MULANAY & 2.70 & 38.90 & 9.45 & 14.40 & 3.50 & 9 & 9 \\
& & & & & & & \\
\hline
\end{tabular}

1) Ave. total weight of fertilizers applied

2) Nut yield/tree/year in 1995 (mean of 2 replicates)

3) $\mathrm{Kg}$ copra yield/tree/year in 1995 (mean of 2 replicates)

4) Nuts/tree/kg fertilizer applied

${ }^{5)} \mathrm{Kg}$ copra/tree/kg fertilizer applied

Ranking of the first five entries are shown below.

CFEn: MRD x BAY > MRD x TAG $>$ MRD x HJT $>$ PGD x LUP $>$ MYD x WAT

CFEc: MRD x TAG $>$ MRD x BAY $>$ MRD x HJT $>$ PGD x LUP $>$ BAY

The CFEs values could be expected to increase when entries reach more stable yield in years to come provided the good level of farm management is maintained.

\section{Mambuaya, Cagayan de Oro City (Barangay Elem. School)}

It is situated in an inland-upland (hilly) area classified as a wet growing zone of coconut with a type B (humid) climate of Northem Mindanao.

In terms of CFEN (Table 5), MRD x HJT is the best entry (CFEn 33.90), followed very closely by MYD x WAT (CFEn = 33.60), while in terms of copra, the MRD x HJT has also the highest CFEc $(=9.29)$ but MRD x BAY $(\mathrm{CFEc}=8.36)$ ranks second. Again the better ranking of 
MRD x BAY over MYD x WAT as far as CFEc is concemed may be largely due to the bigger nut size (or copra weight/nut) of the former,

Table 5. Index of Crop Fertilizer Efficiency (CFE) of Entries in MULTILOC-Mambuaya, Cagayan de Oro City (School-cooperator)

\begin{tabular}{|l|c|c|c|c|c|c|c|}
\hline \multirow{2}{*}{ Entry } & \multirow{2}{*}{ Kg FA $^{1}$} & \multirow{2}{*}{$\mathrm{N} / \mathrm{P}^{2}$} & $\mathrm{C} / \mathrm{P}^{3}$ & \multicolumn{2}{|c|}{ CFE } & \multicolumn{2}{c|}{ CFE Rank } \\
\cline { 5 - 8 } & ave 93-95) & $(1995)$ & $(1995)$ & $\mathrm{CFEn}^{4}$ & $\mathrm{CFEc}^{5}$ & $\mathrm{CFEn}$ & CFEc \\
\hline MYD x WAT & 4.00 & 134.40 & 29.69 & 33.60 & 7.42 & 2 & 4 \\
MYD x RIT & 4.00 & 107.40 & 29.06 & 26.90 & 7.26 & 4 & 5 \\
MRD x RIT & 4.00 & 84.90 & 20.94 & 21.20 & 5.23 & 7 & 7 \\
MRD x TAG & 4.00 & 90.80 & 25.71 & 22.70 & 6.43 & 6 & 6 \\
MRD x BAY & 4.00 & 121.10 & 33.43 & 30.30 & 8.36 & 3 & 2 \\
MRD x HJT & 4.00 & 135.80 & 37.18 & 33.90 & 9.29 & 1 & 1 \\
TAC x BAO & 4.00 & 96.10 & 30.11 & 24.00 & 7.53 & 5 & 3 \\
PGD x LUP & 4.00 & 64.20 & 16.52 & 16.00 & 4.13 & 9 & 9 \\
BAY & 4.00 & 67.50 & 20.80 & 16.90 & 5.20 & 8 & 8 \\
TAG & 4.00 & 54.60 & 13.47 & 13.60 & 3.37 & 10 & 11 \\
LAPASAN & 4.00 & 53.90 & 16.35 & 13.50 & 4.09 & 11 & 10 \\
\hline
\end{tabular}

${ }^{1)}$ Ave. total weight of fertilizers applied

${ }^{2)}$ Nut yield/tree/year in 1995 (mean of 2 replicates)

${ }^{3)} \mathrm{Kg}$ copra yield/tree/year in 1995 (mean of 2 replicates)

${ }^{4)} \mathrm{Nuts} / \mathrm{tree} / \mathrm{kg}$ fertilizer applied

${ }^{5)} \mathrm{Kg}$ copra/tree/kg fertilizer applied

The impressive high CFEs value of entries, both hybrids and talls at nine years from FP mi this MULTILOC site is very likely due to the combination of the favorable climatic conditions and highly effective fertilizer application, resultmig in balance nutrition. of palms. In fact, at early years of palm growth, boron deficiency in the site was detected and subsequently corrected.

Indeed, for hybrids, CFEn $>30$ nuts/kg fertilizer applied (annually) or CFEc $>8 \mathrm{~kg}$ copra $/ \mathrm{kg}$ fertilizer applied is clearly attractive enough.

Ranking of the first five hybrids follows the sequence below.

CFEn MRD x HJT $>$ MYD $x$ WAT $>$ MRD x BAY $>$ MYD x RIT $>$ TAC $x$ BAO

CFEc MRD x HJT $>$ MRD x BAY $>$ TAC x BAO $>$ MYD x WAT $>$ MYD x BAY

\section{Tagum, Davao Norte (TRRC - Hijo Plantation)}

A MULTILOC site located in an inland-flat area classified as a wet growing zone with a type A (wet) climate in Southern Mindanao. Of the eleven (11) entries (Table 6) the best entry is MRD x BAY both in CFEn $(=28.40)$ and CFEc $=(8.78)$, nuts and copra terms, respectively. This was followed by MYD x RIT and MRDxTAG with CFEc of 7.56 and 7.40, respectively.

Among the sites, this site probably reached the initial full-bearing stage carlier than the other sites with high CFEs as PCA-ARC (Albay), Marnbuaya, Cagayan de Oro City and PCA-ZRC (Zamboanga City). Most likely this is attributed to highly favorable climatic and soll conditions, 
including balance nutrition as a result of timely and judicious fertilizer application. This is one of sites which showed boron deficiency during the early years of palm growth and was easily corrected with borax application (20-30 g/tree).

Table 6. Index of Crop Fertilizer Efficiency (CFE) of Entries in MULTILOC - Tagum, Davao Norte ( TRRC-Hijo / School Cooperator)

\begin{tabular}{|l|c|c|c|c|c|c|c|}
\hline \multirow{2}{*}{ Entry } & \multirow{2}{*}{$\begin{array}{c}\mathrm{Kg} \mathrm{FA}^{1} \\
\text { (ave 93-95) }\end{array}$} & \multirow{2}{*}{$\begin{array}{c}\mathrm{N} / \mathrm{P}^{2} \\
(1995)\end{array}$} & $\mathrm{C} / \mathrm{P}^{3}$ & \multicolumn{2}{|c|}{ CFE } & \multicolumn{2}{c|}{ CFE Rank } \\
\cline { 5 - 8 } & 4.38 & 97.80 & 21.66 & 22.30 & 4.94 & 5 & 6 \\
\hline MYD x WAT & 4.38 & 120.50 & 33.12 & 27.50 & 7.56 & 2 & 2 \\
MYD x RIT & 4.38 & 86.10 & 21.21 & 19.60 & 4.84 & 6 & 7 \\
MRD x RIT & 4.38 & 114.30 & 32.43 & 26.10 & 7.40 & 3 & 3 \\
MRD x TAG & 4.38 & 124.50 & 38.48 & 28.40 & 8.78 & 1 & 1 \\
MRD x BAY & 4.38 & 114.00 & 31.18 & 26.00 & 7.12 & 4 & 4 \\
MRD x HJT & 4.38 & 74.90 & 23.63 & 17.10 & 5.39 & 7 & 5 \\
TAC x BAO & 4.38 & 60.40 & 15.50 & 13.79 & 3.54 & 9 & 10 \\
PGD x LUP & 4.38 & 59.40 & 18.19 & 13.56 & 4.15 & 10 & 8 \\
BAY & 4.38 & 70.60 & 17.42 & 16.12 & 3.98 & 8 & 9 \\
TAG & 4.38 & 48.00 & 11.85 & 10.90 & 2.70 & 11 & 11 \\
HJT &
\end{tabular}

Note :

1) Ave. total weight of fertilizers applied

${ }^{2)} \mathrm{Nut}$ yield/tree/year in 1995 (mean of 2 replicates)

${ }^{3)} \mathrm{Kg}$ copra yield/tree/yarn 1995 (mean of 2 replicates)

4) Nuts/tree/kg fertilizer applied

${ }^{5)} \mathrm{Kg}$ copra/tree/kg fertilizer applied

As to the sequence of the best five entries and the CFE analysis showed the following:

CFEn: MRD x BAY $>$ MYD x RIT $>$ MRD x TAG $>$ MRD x HJT $>$ MYD x WAT

CFEc: MRD x BAY $>$ MYD x RIT $>$ MRD x TAG $>$ MRD x HJT $>$ TAC x BAO

These two bases (CFEn and CFEc) have very similar sequences of the CFEs except the replacement of MYD x WAT by TAC x BAO in the CFEc (copra based) as a result of lower copra weight/nut or nut size of the MYD x WAT compared to the hybrid TAC x BAO which has higher copra weight per nut.

\section{Implication of Findings}

With strong confidence, the Crop Fertilizer Use Efficiency (CFE), either in CFEn (nut-based) or CFEc (copra-based) may be used as one of the criteria or practical tools in selecting or identifying planting materlials of coconut for different growing enviromnents or zones in the country. In this technique, same level of desired fertilizer application is applied to all genetic materials tested in the site. Most farms in the Philippines could afford to apply only a moderate rate of fertilizers, usually on a continual basis. 
Moreover, results also suggest that in early years (5-6 years) of coconut production, the application of fertilizers on hybrids increases nut yield by $92 \%$ and copra yield by $106 \%$, over the same fertilization in tall varieties (Table 7 and Figure 2).

Table 7. Coconut Yield Improvement due to Hybrid Vigour (based on Philippines MULTILOC Project, 1983-95)

\begin{tabular}{|c|c|c|c|c|c|c|c|}
\hline \multirow{2}{*}{ Site } & \multirow{2}{*}{$\begin{array}{l}\text { Growing } \\
\text { Zone }\end{array}$} & \multicolumn{2}{|c|}{ Tall (average) } & \multicolumn{2}{|c|}{$\begin{array}{c}\text { Hybrids } \\
\text { (best } 3 \text { ave) }\end{array}$} & \multicolumn{2}{|c|}{ Percentage Advantage } \\
\hline & & $\begin{array}{l}\text { Nut } \\
\text { Yield }\end{array}$ & $\begin{array}{l}\text { Copra } \\
\text { Yield } \\
\end{array}$ & $\begin{array}{l}\text { Nut } \\
\text { Yield }\end{array}$ & $\begin{array}{l}\text { Copra } \\
\text { Yield }\end{array}$ & $\begin{array}{l}\text { Nut } \\
\text { Yield }\end{array}$ & $\begin{array}{l}\text { Copra } \\
\text { Yield }\end{array}$ \\
\hline 1. Piat (CSU), Cagayan & Dry & 1.80 & 0.50 & 19.70 & 5.05 & 994.00 & 910.00 \\
\hline 2. Los Baos (UPLB) & Intermediate & 19.40 & 3.16 & 43.80 & 13.20 & 125.00 & 349.00 \\
\hline 3. Mulanay (Coop) Quezon* & Wet & 39.00 & 10.58 & 67.80 & 18.70 & 73.80 & 76.70 \\
\hline 4. Baybay (ViSCA), Leyte & Wet & 14.00 & 4.32 & 37.80 & 9.50 & 166.00 & 120.00 \\
\hline $\begin{array}{l}\text { 5. Guinobatan (PCA-ARC), } \\
\text { Albay* }\end{array}$ & Wet & 33.90 & 8.10 & 73.10 & 22.90 & 117.00 & 183.00 \\
\hline 6. Carmen (Coop), Bohol & Intermediate & 3.50 & 0.87 & 43.70 & 11.00 & 1148.00 & 1164.00 \\
\hline $\begin{array}{l}\text { 7. Mambuaya (Cooperator) } \\
\text { Cagayan de Oro City* }\end{array}$ & Wet & 58.70 & 16.87 & 117.60 & 33.50 & 100.00 & 98.60 \\
\hline $\begin{array}{l}\text { 8. San Ramon (PCA-ZRC). } \\
\text { Zamboanga City* }\end{array}$ & Intermediate & 51.90 & 15.71 & 86.50 & 24.00 & 66.70 & 53.00 \\
\hline $\begin{array}{l}\text { 9. Tagum (TRRC-Hijo), Davao } \\
\text { Norte* }^{*}\end{array}$ & Wet & 59.30 & 15.82 & 119.80 & 34.70 & 102.20 & 119.30 \\
\hline Mean Effect of Variety $\left(^{*}\right)$ & & 48.56 & 13.42 & 92.96 & 26.76 & 91.94 & 106.12 \\
\hline
\end{tabular}

*site with good to excellent farm management from field-planting 


\section{Coconut Yield Improvement Due to Hybrid Vigour}
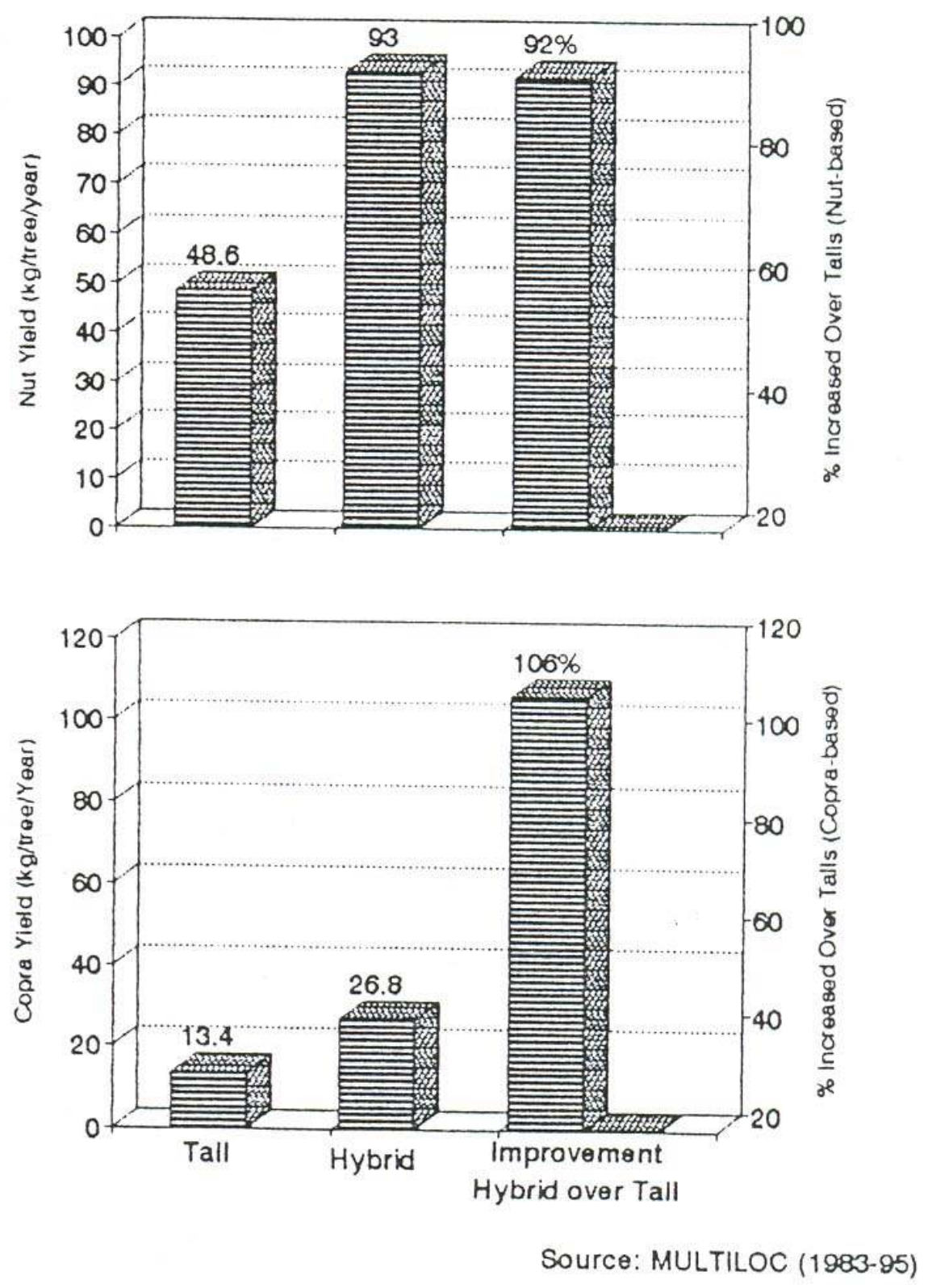

Figure 2. Average Performance of Hyrbids vs. Tall varieties and relative effect on coconut yiled improvement (\%) during early production (5-6) years, under moderate fertilization. 


\section{INTEGRATED SOIL FERTILITY MANAGEMENT (ISFM) OF COCONUT IN A COCONUT-BASED FARMING SYSTEM (CBFS)}

Magat (1991) conceptualized the ISFM and defined it as the combined use of orgaruic/natural and inorganic/mineral fertilizers in coconut farming aimed at reaching maximurn economic yield through a sustainable, economical, environment-friendly arid socially acceptable production system. In most cases, studies involving ISFM are long term ones as the agronomic, soils arid mineral nutrition aspects of farming techniques are thoroughly studied before conclusions arid final recommendations are formulated in under coconut monoculture farming arid CBFS.

In line with this approach, several. studies have been redirected or initiated over the past three years, covening:

1) Nursery seedlings

2) Young arid bearing patins

3) Coconut-Annuals cropping systems

4) Coconut-Perennials cropping systems (e.g. with lanzones fruit crop, banana)

The inorganic fertilizers used in ISFM f6cus on physically blended NPK compound. fertilizers as $14-5-20+0.20 \% \mathrm{~B}\left(14 \% \mathrm{~N}, 5 \% \mathrm{P}_{2} 0_{5}, 20 \% \mathrm{~K}_{2} 0,15.5 \% \mathrm{Cl}, 4.5 \% \mathrm{~S}, 0.20 \% \mathrm{~B}\right)$ which is expected to be switable for both coconut arid intercrops. Other different combinations of organic (commercial or farm compost) arid morgamic fertilizers are tested in on-going studies in the country.

\section{ISFM-in Coconut Stands}

On-farm fertilizer trials or OFFT (In farmers field) is conducted to have site-specific recommendations and provide PCA Research Agronomists arid Extension Agriculturists reference trials in fine-tuning fertilizer recommendations using either mineral (inorganic), organic or the combMiation of the two fertilizer sources. Magat (1979) revealed the usefulness of leaf analysis (foliar diagnosis) in successful conduct of OFFT in Mindanao region, Philippines. He noted positive responses to fertilization of local talls, particularly in areas with clear deficiencies in $\mathrm{Cl}$ and $\mathrm{N}$-based on leaf analysis started by CIRAD-CP (IRHO formerly) in early 60's and developed by PCA in the Philippines (Magat, 1993).

Conduct of OFFT has been continued to cover the whole country involving both the dommiant tall stands and new plantings of hybrids, particularly MAWA introduced in the country by 1RHO. The lack of adequate information on the performance of hybrids under judicious fertilization as MAWA necessitated OFFT of MAWA planted in some areas in the country (about 35,000 has). A recent report of the MULTILOC project (PCARRD-PCA, 1995) indicated appreciable comparable performance of MAWA as promising local hybrids developed by PCA (PCA 15-2, PCA- 3, etc.)

Eleven (11) field trials (1985-1994 on the ISFM of coconut showed that the field response of coconut across sites differed (Table 8), likely due to diverse agroclimatic conditions, nature and extentrol-I nutrient deficiencies as indicated by leaf N, K, P, Cl, S and B (Table 9). Generally, higher Yield response was reached $\mathrm{m}$ mtennechate arid wet growing zones wifs strong deficiencies in $\mathrm{Cl}$ and N (using critical and optimum levels followed by PCA - Magat et al 1979, 1989). Average response of coconut (talls and hybrids) with application of inorganic fertilizers (IF) of $14.2 \mathrm{~kg}$ copra/tree per year; to organic fertilizer (OF), $11.8 \mathrm{~kg}$ copra; to IF plus OF, $14.5 \mathrm{~kg}$ copra/tree; and of control palms (soil inherent nutrients), $8.1 \mathrm{~kg}$ copra. These correspond to average increase of $127.6 \%$ (IF), $61.9 \%$ (OF) and $125.8 \%$ (OF plus IF) compared to unfertilized palms, respectively. 
Results also indicate: (1) higher increases in sites with strong deficiencies $\mathrm{m} \mathrm{Cl}$ and $\mathrm{N}$ (Tupi, Gwisao, Tabaco, Cogon, Bayugan) (Table 5. 1b); [2) after 3-4 years of annual fertilizer application of OF singly was as effective as IF singly in sites mainly deficient in either N, P, K or 6 all; and [3] higher yields of OF plus IF over either application of OF or IF singly were obtained under strong multiple deficiencies in $\mathrm{N}, \mathrm{P}, \mathrm{K}$ arid $\mathrm{Cl}$.

Therefore, in ISFM both the agronomic effectiveness and the cost-efficiency should be considered in determining the economic viability of the ISFM in coconut production; especially in long-term fertilization (regular or continual).

In the immediate improvement of yield of coconut stands, application of mineral fertilizers appears a better option, particularly if farm supply of organic fertilizer materials are limited and expensive. Anyway, with high yields and increased coconut farm residues this usually results in higher supply of farm biomass which gradually builds up the organic matter of the soll via biological enrichment of the soil humus and inorgamic nutrient supplymig capacity to coconut and intercrops.

Table 8. Summary of Yield Response (Copra/Tree/year) to ISFM in Eleven (11) Nationwide Trials (1985-1996), Philippines

\begin{tabular}{|c|c|c|c|c|c|c|c|c|}
\hline Trial Sites & Period & $\begin{array}{l}\text { Control } \\
\text { Unfert } \\
\text {-(UF) }\end{array}$ & \multicolumn{2}{|c|}{$\begin{array}{c}\text { Inorganic } \\
\text { Fertilizer } \\
\text { (IF) }\end{array}$} & \multicolumn{2}{|c|}{$\begin{array}{c}\text { Organic } \\
\text { Fertilizer } \\
\text { (OF) }\end{array}$} & \multicolumn{2}{|c|}{$\mathrm{IF}+\mathrm{OP}$} \\
\hline 1. Tupi, South Cotabato & $1985-93$ & 7.2 & 26.6 & $(269 \%)$ & 6.8 & $(-6 \%)$ & 17.0 & $9136 \%)$ \\
\hline 2. Solana, Tuguegarao & $1985-93$ & 2.5 & 5.6 & $(124 \%)$ & 4.2 & $(68 \%)$ & 6.0 & $(140 \%)$ \\
\hline 3. Guisao, Zamboanga City & $1985-93$ & 1.3 & 8.1 & $(573 \%)$ & 3.4 & $(162 \%)$ & 8.0 & $(515 \%)$ \\
\hline 4. Tabaco Albay & $1986-94$ & 8.8 & 14.8 & $(78 \%)$ & 12.5 & $(58 \%)$ & 15.4 & $(84 \%)$ \\
\hline 5. Batan, Aklan & $1986-94$ & 9.6 & 11.6 & $(21 \%)$ & 10.4 & $(8 \%)$ & 10.3 & $(7 \%)$ \\
\hline 6. Cogon, Dipolog City & $1986-94$ & 5.1 & 8.3 & $(63 \%)$ & 9.5 & $(86 \%)$ & 10.4 & $(104 \%)$ \\
\hline 7. Mauban, Quezon & $1986-94$ & 11.2 & 12.1 & $(8 \%)$ & 15.1 & $(35 \%)$ & 15.1 & $(35 \%)$ \\
\hline 8. Baliangao, Misamis Occ. & $1987-95$ & 9.2 & 14.6 & $(60 \%)$ & 15.4 & $(68 \%)$ & 16.8 & $(84 \%)$ \\
\hline 9. Lale, samar & $1987-95$ & 19.9 & 27.1 & $(36 \%)$ & 26.4 & $(33 \%)$ & 30.5 & $(54 \%)$ \\
\hline 10. Sipocot, Camarines Sur & $1987-95$ & 6.2 & 10.0 & $(61 \%)$ & 10.0 & $(61 \%)$ & 11.7 & $(89 \%)$ \\
\hline 11. Bayugan, Agusan Sur & $1987-95$ & 8.0 & 16.9 & $(111 \%)$ & 16.6 & (1085) & 18.9 & $(136 \%)$ \\
\hline Range & & $\begin{array}{l}1.3- \\
19.9\end{array}$ & $\begin{array}{c}5.6- \\
27.1\end{array}$ & $\begin{array}{r}(8 \%- \\
(573 \%)\end{array}$ & $\begin{array}{c}2.4- \\
26.4\end{array}$ & $\begin{array}{c}(-6 \%- \\
162 \%)\end{array}$ & $\begin{array}{r}6- \\
30.5\end{array}$ & $\begin{array}{r}(7 \%- \\
515 \%)\end{array}$ \\
\hline Mean & & 8.1 & 14.2 & $(128 \%)$ & 11.8 & $(62 \%)$ & 14.6 & $(126 \%)$ \\
\hline
\end{tabular}

Table 9. Salient Information on the different OFFT sites. Philippines (1985-95)

\begin{tabular}{|l|c|c|c|c|}
\hline \multicolumn{1}{|c|}{ OFFT Site/Growing Zone } & $\begin{array}{c}\text { Duration } \\
(8 \text { yrs })\end{array}$ & Land Form & $\begin{array}{c}\text { Estimated } \\
\text { Age at start }\end{array}$ & $\begin{array}{c}\text { Planting } \\
\text { Material }\end{array}$ \\
\hline 1. Plonuling, S. Cotabato/Int. & $1985-93$ & inland-Flat & 4 yrs. & MAWA \\
2. Tuguegarao, Cagayan/Dry & $1985-93$ & inland-upland & 4 yrs. & MAWA \\
3. Guisao, Zamboanga city/int. & $1985-93$ & inland-upland & 3 yrs. & MAWA \\
4. Tabaco, Albay/Wet & $1985-93$ & inland-upland & 3.5 yrs & MAWA \\
5. Batan, Aklan/Wet & $1986-94$ & inland-upland & 23 yrs. & Local Tall \\
6. Cogon, Dipolog City/Wet & $1986-94$ & inland-upland & 5 yrs. & MAWA \\
7. Mauban, Quezon/Wet & $1986-94$ & inland-upland & 26 yrs. & Local Tall \\
8. Baliangao, Misamis Occ./Wet & $1986-94$ & inland-upland & 3 yrs. & MAWA \\
9. Lale, Samar/Wet & $1987-95$ & inland-upland & 20 yrs. & Local Tall \\
10, Sipocot, Cam. Sur/Int. & $1987-95$ & inland-upland & 30 yrs. & Local Tall \\
11. Bayugan, Agusan Sur/Wet & $1987-95$ & inland-upland & 4 yrs. & MAWA \\
& & & & \\
\hline
\end{tabular}


Table 9. Continuation

\begin{tabular}{|c|c|c|c|c|c|c|c|c|c|}
\hline \multirow[b]{2}{*}{ OFFT Site/Growing Zone } & \multicolumn{9}{|c|}{ E L E M E N T S (\% in dry matter) 1} \\
\hline & $\mathrm{N}$ & $\mathrm{P}$ & $\mathrm{K}$ & $\mathrm{Ca}$ & $\mathrm{Mg}$ & $\mathrm{Na}$ & $\mathrm{Cl}$ & $\mathrm{s}$ & $\begin{array}{c}\mathrm{B} \\
(\mathrm{ppm})\end{array}$ \\
\hline 1. Plonuling, S. Cotabato/Int. & 2.180 & 0.150 & 1.646 & 0.030 & 0.220 & 0.151 & 0.208 & 0.187 & 13.4 \\
\hline 2. Tuguegarao, Cagayan/Dry & 1.487 & 0.137 & 0.965 & 0.344 & 0.366 & 0.308 & 0.580 & 0.170 & 9.7 \\
\hline 3. Guisao, Zamboanga city/int & 1.639 & 0.107 & 0.600 & 0.258 & 0.363 & 0.284 & 0.071 & 0.159 & 11.9 \\
\hline 4. Tabaco, Albay/Wet & 1.351 & 0.103 & 0.729 & 0.268 & 0.240 & 0.540 & 0.341 & 0.137 & 9.5 \\
\hline 5. Batan, Aklan/Wet & 1.457 & 0.111 & 2.019 & 0.230 & 0.381 & 0.163 & 0.740 & 0.115 & 12.5 \\
\hline 6. Cogon, Dipolog City/Wet & 1.814 & 0.106 & 0.899 & 0.236 & 0.432 & 0.222 & 0.222 & 0.124 & 13.3 \\
\hline 7. Mauban, Quezon/Wet & 1.870 & 0.116 & 0.668 & 0.202 & 0.216 & 0.453 & 0.685 & 0.151 & 8.7 \\
\hline $\begin{array}{l}\text { 8. Baliangao, Misamis } \\
\text { Occ./Wet }\end{array}$ & 1.481 & 0.088 & 1.413 & 0.185 & 0.254 & 0.235 & 0.404 & 0.146 & 9.5 \\
\hline & 1.726 & 0.125 & 1.360 & 0.234 & 0.305 & 0.195 & 0.168 & 0.154 & 8.8 \\
\hline 10, Sipocot, Cam. Sur/Int. & 1.732 & 0.117 & 0.262 & 0.252 & 0.444 & 0.245 & 0.602 & 0.130 & 16.0 \\
\hline 11. Bayugan, Agusan Sur/Wet & 1.539 & 0.124 & 0.498 & 0.235 & 0.467 & 0.197 & 0.351 & 0.175 & 10.1 \\
\hline
\end{tabular}

1) italicized values considered deficiency status of coconut

To summarize, Table 10 and Figure 3 highlight results obtalned in farmers fields in terms of the yield increase due to long-term fertilization of talls and hybrids clearly showed the former had an average increase of $50 \%$ and the latter a remarkable $196 \%$ increase or the average response to fertilization was $123 \%$.

Table 10. Coconut Yield Improvement due to Fertilization (based on PCA on-Farm Fertilizer Trials, 1985-95)

\begin{tabular}{|c|c|c|c|c|c|}
\hline \multirow[t]{2}{*}{ Site } & \multirow{2}{*}{$\begin{array}{l}\text { Material } \\
\text { (variety/ } \\
\text { Hybrid) }\end{array}$} & \multirow{2}{*}{$\begin{array}{c}\text { Growing } \\
\text { Zone }\end{array}$} & \multicolumn{2}{|c|}{$\begin{array}{c}\text { Average Copra Yield } \\
\text { t/tree/year }\end{array}$} & \multirow{2}{*}{$\begin{array}{c}\% \text { Advantage } \\
\text { of } \\
\text { fertilization }\end{array}$} \\
\hline & & & Unfert & Fertilized & \\
\hline 1. Tupi, South Cotabato & Hybrid* & Intermediate & 7.2 & 26.6 & 269 \\
\hline 2. Tuguegarao, Cagayan & Hybrid & Dry & 2.5 & 5.6 & 124 \\
\hline 3. Guisao, Zamboanga & Hybrid & Intermediate & 1.3 & 8.1 & 573 \\
\hline 4. Tabaco, Albay & Hybrid & Wet & 8.8 & 15.4 & 84 \\
\hline 5. Cogon, Dipolog City & Hybrid & Wet & 5.1 & 10.4 & 104 \\
\hline 6. Baliangao, Misamins Oc & Hybrid & Wet & 9.2 & 16.8 & 84 \\
\hline 7. Bagayan, Agusan Sur & Hybrid & Wet & 8.0 & 18.9 & 136 \\
\hline \multicolumn{3}{|c|}{ MEAN for HYBRIDS } & 6.0 & 14.5 & 196 \\
\hline 8. Batan, Aklan & Local Talls & Wet & 9.6 & 11.6 & 21 \\
\hline 9. Mauban, Quezon & Local Talls & Wet & 11.2 & 15.1 & 35 \\
\hline 10. Lale, Samar & Local Talls & Wet & 19.9 & 30.5 & 54 \\
\hline 11. Sipocot, Cam. Sur & Local Talls & Intermediate & 6.2 & 11.7 & 89 \\
\hline \multicolumn{3}{|c|}{ MEAN for TALLS } & 11.7 & 17.2 & 50 \\
\hline \multicolumn{5}{|c|}{ AVERAGE RELATIVE EFFECT OF FERTILIZATION (\% INCREASE) } & 123 \\
\hline
\end{tabular}

*MAWA 
The PCA had to date released for farmers used nine (9) coconut hybrids of the Dwarf $\mathrm{x}$ Tall cross (PCA-ARDB Report 1996). One of the latest ones is the TACxBAO (PCA 15-8). a high yielding ( $5 \mathrm{t} / \mathrm{ha}$ copra), with medium to large size nuts ( $310 \mathrm{~g}$ copra/nut and $39 \mathrm{~kg}$ copra/tree/year) which usually produces the initial nut harvest in 4 years time from field-planting when applied with moderate fertilization rates $\left(1.5 \mathrm{~kg}\left(\mathrm{NH}_{4}\right)_{2} \mathrm{SO}_{4}\right.$ plus $2 \mathrm{~kg} \mathrm{KCI}$ or $1.5 \mathrm{~kg} \mathrm{NaCl} /$ tree/year) (Figure 4). It contains MCT $\left(\mathrm{C}_{5}-\mathrm{C}_{12}\right)$ of $73.31 \%$ and Lauric acid(- $\left.\mathrm{C}_{12}\right)$ of $52.6 \%$.

\section{COCONUT YIELD IMPROVEMENT DUE TO FERTILIZATION}



Source PCA On-Farm-Field-Trials (1985-95) in eleven (11) sites in dry intermediate and wet growing zones

Figure 3. Relative Yield Response of Tall and Hybrid coconut Under Farmer's Field 




\section{SUMMARY AND CONCLUSION}

1) In recent years, the application of package of technologies (POT) on fertilization in coconut farms in the country have demonstrated significant improvement in reducing the peld gaps between those obtained in research stations and farmers' fields by only 24 nut/tree or $0.90 \mathrm{t}$ copra/year, annually.

2) Under unmanaged farm, average annual yields are: 35 nuts/tree or $1.02 \mathrm{t}$ copra/ha, while PCA research stations achieved 107 nuts/tree or $3.6 \mathrm{t}$ copra/ha.

3) Even in the early production years (5-6 years), promising coconut hybrids increased nut production by $92 \%$ and copra yield by $106 \%$ over the traditional tall varieties under similar growing conditions and same moderate fertilization levels. This clearly shows the hybrid vigor and positive phenotypic expression of desirable coconut hybrids in a multilocation expeniment cum demonstration, nationwide.

4) In a 10 year on-farm fertilizer trials in some dry, intermediate and wet growing zones, using local talls and hybrids, the average response (\% relative yield) achieved were $196 \%$ and $50 \%$ for hybrids and tall variety, respectively, or translated to an average of $123 \%$ yield improvement due to feftihzation. This indicates that most coconut soils in the country have inadequate supply of soll nutrients, particularly, nitrogen, chloride, sulfur and potassimn. However, there are indications that increasing hectarage of coconut would likely need both phosphorus and magnesium soon. 
5) The application of chloride fertilizers $\left(\mathrm{KCl}, \mathrm{NaCl}, \mathrm{NH}_{4} \mathrm{CI}\right)$ makes fertilization, agronomically effective and allows palm to have balance nutrition needed to increase the maximum economic yield (MEY). Thus, the organic fertilizers should not be applied singly on coconut, especially if palms are deficient in chlorine.

6) For profitable and sustainable coconut farming, the integrated soil fertility management or ISFM. using all avallable organic fertilizer sources also as soil conditioner and soll moisture enhancer) plus inorganic or chemical fertilizers to complete/ balance the coconut nutrition should be always practiced. This will optimized the benefits in using genetically excellent tall varieties and hybnids, ensuning success of any replanting or rehabilitation effort. 


\section{REFERENCES}

MAGAT, S.S. 1976. Soll and leaf analysis in relation to coconut Yleld. Phil. J. Coconut Studies $1(2): 1-12$.

MAGAT. S. S. 1978. The use of leaf analysis in the conduct of fertilizer trials in the Philippines. Proc. 8th Int'1. Colloquium on Plant Analysis and Fertilizer Problems. New Zealand D.S.I.R. Info Series No. 134:299-311. Also in: Phil, J. Coconut Studies 4(1):32-39.

MAGAT, S.S. 1995. A Guide in estimating the yield or productivity of coconuts. Technology Notes 7 CANFARMS, Phil. Coconut Authority. 8 p.

MAGAT, S.S. 1996. Search for a better understanding of the Mineral Nutrition and Fertilizer Needs of Coconuts in the Philippines Towards a Reliable Nutrition Management and Fertilizer Recommendations: From 1964 to 1996 and Beyond. Coconut R\&D Symposium. 30 Years Founding Anniversary of the PCA-Davao Research Center, Bago-Oshiro. Davao City, 6th February 1996. 38 p.

MAGAT, S.S. and R.Z. MARGATE. 1990. The Chlormic Needs of Coconuts, CORD 7(1.): 30-5 1.

MAGAT, S.S. Coconut Industry in the Philippmies, Occasional Publication Series, No. 14. Djakarta, Indonesia: APCC, 1991. $94 \mathrm{p}$.

MAGAT, S.S., G.D. PADRONES and L.M. ALFORJA. 1992. Residual Effects of three Chloride Fertilizers on Yield and Leaf Nuthent Levels of Coconuts Grown on an Inland Soil of Davao (Mindanao, Philippmies). Oleagineux 48(5):237242.,

MAGAT, S.S., L.M. ALFORJA and L.G. OGUIS. 1989. An Estimation of the Critical and Optimum Levels of Leaf-Chlorine in Beaning Coconuts: A Guide for Foliar Diagnosis. Phil.J.Coconut Studies 13(1): 6-9.

MAGAT, S.S.; L.M. ALFORJA and R.Z. MARGAINIO 1987. An estimation of the ptimum and critical levels of leaf-sulfur concentration in bearing coconuts (local tall). Phil, J. Coconut Studies B(1):6-9.

MANCIOT, R- et. al. Mineral Nutrition and Fertilization of Coconut around the world. Oleagineux 34(11), 500-515 (ID79).

PCA. 1996. Coconut Yield Assessment Report: Coconut Rehabilitation by Fertilization Component. The Small Coconut Farms Development Project - Philippines (WB-PH3204). SCFDP-CYA: Report No. 1/96. Philippine Coconut Authority-Region XI, Davao City. 72 p.

PCARRD/PCA. 1995. Regional Testing of Promosing Coconut Hybrids and Cultivars (MULTILOC Project). Phase IV Report. Los Banos, Laguna. 75 p.

The Coconut Committee. 1992. The Philippines recommends for coconut. Los Banos, Laguna: PCARRD, PARRFI and PCRDF. 1993. 234 p. (Philippine Recommends Series. No. 2B/1992). 